UDC 621.315.051.024: 621.3 .025

621.314 .58

\title{
交直連系系統に打りる交流電圧安定度 解析手法の開発
}

\author{
電力中央研究所 吉 田 幸 雄
}

\section{1. まえがき}

将来，直流送電の発展上与もに，長距隻大容量送 電, 離島への送電, 負荷過密地域への送電に直流送電 在道用することが考えられ，この場合には従来の直流 送電系統にくらへ苜流系容量吕增大し交流系統容量上 直流系容量の比が小となる傾向が考えられる。このよ うに, 交流系の短絡容量 $W$, 之直流系容量 $P_{d N}$ の比 $W: / P_{d, N}$ 㔔小さくなると，順变換器は主として交直 逞系電王の高調波波形ひずみによる高調波不安定掁 動，逆変換器は主として

（i）交直連遑系点の基本波交流電圧变勳特性上順 ・逆变換器の制御系江関連立る不安定振動

(ii) 交流系縄のリアクタンスと変換器用フィルタ タのコンデンサと加高調波共振回路を形成さる場合の 高調波振動を発生する。

上記（１）の基本波交流電任变動江上る不安定現象は 交流電珐安定度之呼ばれている。(1)

順变換器の高調波不安定現象の解明江は種々の研究 がなされて衫り，安定運転限界や高調波安定度老向上 する位相制御方式加明らかとされている。(3)(4) 変換器の交流電圧安定度については变換器制御系の㭙 定数，利得老無視した場合に交流ならびに直流系の系 統条件や变換器の制御条件が電圧安定度に与える影響 它定性的に蚞討した研究や，安定荤転限界老実験的に 求めた定量的な研究がなさ机ている。(1)(2) しかし，逆 变換器の交流電圧安定㹂は変換器制御系の時定教, 利 得に大きく影響され，さらに交流ならびに直流系統の 系統条件に上って屯左右されるので，乙れを一般的に

Deveropment of a Calculated Method of AC Voltage Stability in HVDC Transmission System. By Y. YOSHIDA, Member (Central Research Institute of Electric Power Industry) 吉田幸婎：正具，電力中央研究所接衙第一研究所電力第 2 部

\begin{tabular}{|cc|}
\hline 論 & 文 \\
\hline $49-B$ & 23 \\
\hline
\end{tabular}




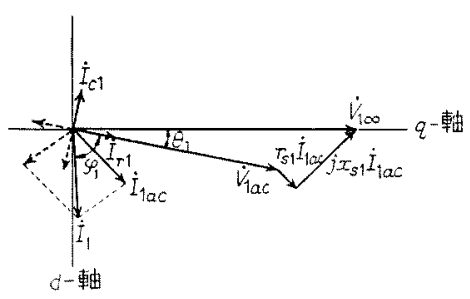

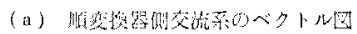

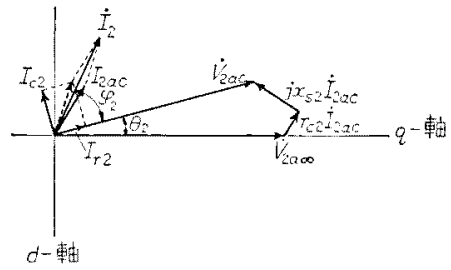

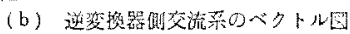

第 2 龱 交直連采々統のベクトル图

Fig. 2. Vector diagram of AC-DC power transmission system.

第 1 表 使用した主なる記号

Table 1. Main symbols used.

\begin{tabular}{|c|c|c|}
\hline & 要 & 号" \\
\hline 采 & 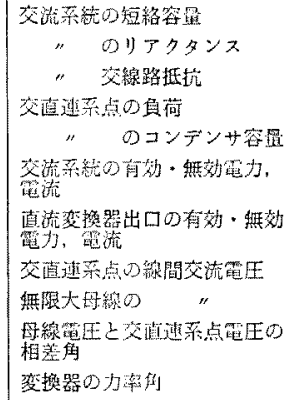 & $\begin{array}{c}W_{s_{1}}, W_{s_{2}} \\
x_{s_{1},} x_{s_{2}} \\
r_{s_{1}}, r_{s_{2}} \\
P_{L_{3}}, P_{L_{2}}\left(r_{L_{2}}, r L_{2}\right) \\
Q_{c_{1}}, Q_{c 2}\left(1 / Y_{c_{1}}, 1 / Y_{c 2}\right) \\
P_{2 a c}, Q_{1 a c}, I_{1 a c}, P_{2 a c}, Q_{z a c}, I_{2 a c} \\
P_{1}, Q_{1,} I_{1}, P_{2}, Q_{2,} I_{2} \\
V_{1 a c}, V_{z a c} \\
V_{1+\infty}, V_{z_{\infty}} \\
\theta_{1}, \theta_{2} \\
\varphi_{1,}, \varphi_{2}\end{array}$ \\
\hline 絤 & 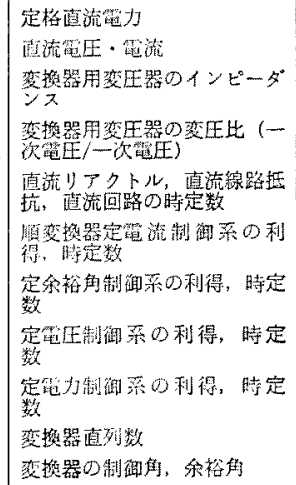 & $\begin{array}{c}P_{d N} \\
E_{d_{1},} E_{d_{2},} I_{d} \\
x_{\ell_{1}}, x_{\ell_{2}} \\
n \\
L_{d,}, R_{d_{2}} T_{d} \\
k_{1}, T_{1} \\
k_{2}, T_{2} \\
k_{3}, T_{3} \\
k_{5}, T_{5} \\
m \\
\alpha, \beta, \delta\end{array}$ \\
\hline
\end{tabular}

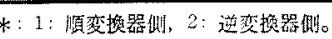

$\dot{I}_{c 1}=j Y_{c 1} \dot{V}_{1 a c}$

$\dot{I}_{r 1}=\dot{V}_{1 a c} / r_{L 1}$

$\dot{I}_{1 a c}=\dot{I}_{1}+\dot{I}_{c 1}+\dot{I}_{r 1}$

$P_{1}=V_{1 a c} I_{1} \cos \varphi_{1}$

$$
Q_{1}=V_{1 a c} I_{1} \sin \varphi_{1}
$$

ここで， $I_{1}$ は変昳器直流巻線に流机る線電流 $I_{1 t}$ のV倍であり， $I_{1}=\sqrt{3} I_{1 l}$ で表わされる。

第 2 図のベクトル図上(5),(6) 式より(7)式が成 立つ。

$$
\tan \theta_{1}=\frac{x_{s 1}\left(P_{1}+P_{L 1}\right)-r_{s 1}\left(Q_{1}+Q_{c 1}\right)}{r_{s 1}\left(P_{1}+P_{L 1}\right)+x_{s 1}\left(Q_{1}+Q_{c 1}\right)+V_{1 a c}{ }^{2}}
$$

同様にして逆变換器侧交流系に対して屯，次の関倸 式が成立する。

$$
\begin{aligned}
& \dot{V}_{2 a c}=\dot{V}_{2 \infty o}+\left(r_{s 2}+j x_{s 2}\right) \dot{I}_{2 a c} \\
& \dot{I}_{c 2}=j Y_{c 2} \dot{V}_{2 a c} \\
& \dot{I}_{r 2}=\dot{V}_{2 a c} / r_{L 2} \\
& \dot{I}_{2}=\dot{I}_{c 2}+\dot{I}_{\tau 2}+\dot{I}_{2 a c} \\
& P_{2}=V_{2 a c} I_{2} \cos \varphi_{2} \\
& Q_{2}=V_{2 a c} I_{2} \sin \varphi_{2}
\end{aligned}
$$

ここで， $I_{2}$ は線電流 $I_{2 l}$ の $\sqrt{3}$ 倍であり， $I_{2}=$ $\checkmark 3 I_{2 t}$ で表わさ机る。

$$
\tan \theta_{2}=\frac{x_{s 2}\left(P_{2}-P_{L 2}\right)-r_{s 2}\left(Q_{2}-Q_{c 2}\right)}{V_{2 a c^{2}}-x_{s 2}\left(Q_{2}-Q_{c 2}\right)-r_{s 2}\left(P_{2}-P_{L 2}\right)}
$$

また，交直連系点の電流関係式は次のようになる。

$$
\begin{aligned}
& I_{1} \fallingdotseq \sqrt{3}\left(\frac{m}{n}\right)\left(\frac{\sqrt{6}}{\pi}\right) I_{d} \\
& I_{2} \fallingdotseq \sqrt{3}\left(\frac{m}{n}\right)\left(\frac{\sqrt{6}}{\pi}\right) I_{d}
\end{aligned}
$$

上記の関係式 (1) (4) と(8) (11) 式を $a-q$ 䡃 成分に分解し，(15)，(16)式を用いると次式を得る。

$$
\begin{aligned}
& i_{d 1}{ }^{2}+i_{q 1}{ }^{2}=\left(\frac{m}{n}\right)^{2} \frac{18}{\pi^{2}} I_{d}{ }^{2} \ldots \ldots \ldots \ldots \ldots . . . \ldots \\
& i_{q 1} \cos \theta_{1}+i_{d 1} \sin \theta_{1}=\left(\frac{m}{n}\right) \frac{\sqrt{18}}{\pi} I_{d} \cos \varphi_{1}
\end{aligned}
$$

$$
\begin{aligned}
& i_{d 2^{2}}+i_{q 2}{ }^{2}=\left(\frac{m}{n}\right)^{2} \frac{18}{\pi^{2}} I_{d^{2}} \ldots \ldots \ldots \ldots \ldots . \ldots(19) \\
& i_{q 2} \cos \theta_{2}-i_{d 2} \sin \theta_{2}=\left(\frac{m}{n}\right) \frac{V \overline{18}}{\pi} I_{d} \cos \varphi_{2}
\end{aligned}
$$

$\langle 2 \cdot 2\rangle$ 直流系の関係式 周知のように直流系で は次の関係式が成り立つ。

$$
\begin{array}{r}
E_{d 1}=\left\{1.35 \frac{V_{1 a c}}{n} \cos \alpha-\left(\frac{3 X_{1}}{\pi}+r_{1}\right) I_{d}\right\} \times m \\
\ldots \ldots \ldots \ldots \ldots \ldots \ldots \ldots \ldots \ldots \ldots \ldots \ldots \ldots \ldots \ldots \ldots \ldots \\
E_{d 2}=\left\{1.35 \frac{V_{2 a c}}{n} \cos \beta+\left(\frac{3 X_{2}}{\pi}+r_{2}\right) I_{d}\right\} \times m
\end{array}
$$


(22)

$\cos \varphi_{1}=\cos \alpha-\frac{X_{1} I_{d}}{V 2 V_{1 a c} / n}$

$\cos \varphi_{2}=\cos \beta+\frac{X_{2} I_{d}}{V} \frac{V_{2 a c} / n}{V}$

$\cos \delta-\cos \beta=\frac{\sqrt{2} X_{2}}{V_{2 a c} / n} I_{d}$

$L_{d} \frac{d I_{d t}}{d t}+R_{d} I_{d}=E_{d 1}-E_{d 2}$

ただし， $X_{1}, X_{2}$ : 変換器の転流りアクタンス,

$r_{1}, r_{2}:$ 变換器 0 内部抵抗

また，(23），(18）式及び交流系の電圧関係式上り順 变換器側已近変撸器側についておのおの次式が成り立 د。

$$
\begin{array}{r}
v_{d t 1} i_{d 1}+v_{q t 1} i_{q 1}=\left(\frac{m}{n}\right) \frac{v \overline{18}}{\pi} V_{1 a c} I_{d d} \cos \alpha \\
\quad-\frac{3 m}{\pi} X_{1} I_{d}{ }^{2} \ldots \ldots \ldots \ldots \ldots \ldots \ldots(27) \ldots \ldots \ldots \ldots \\
v_{d t 2} i_{d 2}+v_{q t 2} i_{q 2}=\left(\frac{m}{n}\right) \frac{v \overline{18}}{\pi} V_{2 a c} I_{d d} \cos \beta \\
+\frac{3 m}{\pi} X_{2} I_{d}{ }^{2}
\end{array}
$$

順・逆変換器の制御采の関係式は制御方式の理類に より次のようになる。ただし，開ループ余裕角制御系 以外の制御菜は一次渥机系で近似し，開ループ余裕角 制御系の時定数は無視した。

(1) 順变換器定電流制御 $(A C R)$, 逆変換器: 定余裕角制御 $(A \delta R)$ の場合

$A C R$ 菜

$$
T_{1} \frac{d \alpha}{d t}+\alpha=-k_{1}\left(I_{d s} I_{d}\right)
$$

$\mathrm{A} \delta \mathrm{R}$ 柔

$$
\begin{aligned}
& T_{2} \frac{d \beta}{d t}+\beta=k_{2}\left(\delta_{s}-\delta\right)(\text { 閉ループ }) \\
& \cos \beta=\cos \delta_{s}-\frac{\sqrt{2} X_{2}}{V_{2 a c} / n} I_{d}(\text { 開ループ })
\end{aligned}
$$

(2) 逆変換器 定電圧制御 $(A V R)$ D場合 $A V R$ 采

$$
T_{3} \frac{d \beta}{d t}+\beta=-k_{3}\left(E_{d 2 s}-E_{d 2}\right)
$$

(3) 逆变換器 定電流制御 $(A C R)$ ○場合 $A C R$ 柔

$$
T_{i} \frac{d \beta}{d t}+\beta=k_{i}\left(I_{d s}-I_{d}\right)
$$

（4）㮌变换器 定電力制衙 $(A P R)$ の場合
$A P R$ 采

$$
T_{5} \frac{d \alpha}{d t}+\alpha=-k_{5}\left(P_{d s}-P_{d}\right)
$$

ただし， $I_{d s}, \delta_{s}, E_{d 2 s}, P_{d s}:$ おの扔の直流雷 流設定值, 余裕角設定值, 直流電圧設定值,

\section{電力設定値}

\section{〈2.3〉微少变動分に対する関係式}

（1）交流系の関倸式 上記の交流系の関保式在 初期值 (平衡点) の近傍の微少変動分について变分し, $\Delta V_{1 a c}, \Delta I_{d}, \Delta \alpha$ と $\Delta_{2 a c}, \Delta I_{d}, \Delta \beta$ に注目して整理す れば次の関倸式力成立する。

順变換器側交流䒺統に刘して

$$
f_{1} \Delta V_{1 a c}+f_{2} \Delta I_{\alpha}+f_{3} \Delta \alpha=0
$$

逆変換器側交流䒺に対して

$$
g_{1} \Delta V_{2 a c}+g_{2} \Delta I_{d}+g_{3} \Delta \beta=0
$$

ただし， $f_{1} \sim f_{3}, g_{1} \sim g_{3}:$ 菜統条件已初期条

体より定学定数

分成り立つ。

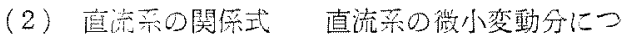
いては，次の関倸式が成り立つ。

$$
\begin{aligned}
\Delta E_{d 1}= & 1.35 \frac{m}{n} \cos \alpha_{0} \Delta V_{1 a c} \\
& -1.35 \frac{m}{n} V_{1 \alpha c 0} \sin \alpha_{0} \Delta \alpha \\
& -m\left(\frac{3 X_{1}}{\pi}+r_{1}\right) \Delta I_{d} \ldots . .
\end{aligned}
$$

$\Delta E_{d 2}=1.35 \frac{m}{n} \cos \beta_{0} \Delta V_{2 a c}$

$$
\begin{aligned}
& -1.35 \frac{m}{n} V_{2 a c 0} \sin \beta_{0} \Delta \beta \\
& +m\left(\frac{3 X_{1}}{\tau}+r_{2}\right) \Delta I_{d} \ldots . .
\end{aligned}
$$

$L_{d t} \frac{d \Delta I_{d}}{d t}+R_{d} \Delta I_{t}=\Delta E_{d 1}-\Delta E_{d 2}$

$T_{1} \frac{d \Delta \alpha}{d t}+\Delta \alpha=k_{1} \Delta I_{d}$

$$
T_{2} \frac{d \Delta \beta}{d t}+\Delta \beta=-k_{2} \Delta \delta
$$

$$
\Delta \beta=\frac{\sqrt{2} X_{2} n}{V_{2 a c 0} \sin \beta_{0}}\left(\Delta I_{a}-\frac{I_{d 0}}{V_{2 a c 0}} \Delta V_{2 a c}\right)
$$

$T_{3} \frac{d \Delta \beta}{d t}+\Delta \beta=k_{3} \Delta E_{d t}$

$T_{4} \frac{d \beta}{d t}+\Delta \beta=-k_{4} \Delta I_{d}$

$$
T_{5} \frac{d \Delta \alpha}{d t}+\Delta \alpha=k_{5} \Delta P_{d}
$$




$$
\begin{aligned}
& =k_{5}\left(E_{d 10} \Delta I_{d}+I_{d 0} \Delta E_{d \mathrm{1}}\right) \\
\Delta \delta & =-c_{1} \Delta I_{d}+c_{2} \Delta \beta \ldots \ldots \ldots
\end{aligned}
$$

ただし

$$
\begin{aligned}
& c_{1}=\frac{\sqrt{2} X_{2 n}}{V_{2 a c 0} \sin \delta_{0}}\left(1+\frac{g_{2} I_{d 0}}{g_{1} V_{2 a c 0}}\right) \\
& c_{2}=\frac{1}{\sin \delta_{0}}\left(\sin \beta_{0}-\frac{\sqrt{2} g_{3} X_{2} I_{d 0}}{g_{1} V_{2 a c 0^{2} / n}}\right)
\end{aligned}
$$

（3）交直連系々統の以態方程式

(35), (36)式 を(37)（39) 式に代入して $\Delta I_{d}, \Delta \alpha, \Delta \beta$ の関係式に まとわる次式を得る。

$$
\begin{aligned}
\frac{d \Delta I_{d}}{d t}= & \frac{B_{1}-B_{2}-R_{d}}{T_{d} R_{d}} \Delta I_{d} \\
& -\frac{B_{3}}{T_{d} R_{d}} \Delta \alpha+\frac{B_{4}}{T_{d} R_{d}} \Delta \beta
\end{aligned}
$$

ただし

$$
\begin{aligned}
& B_{1}=1.35 \frac{m}{n} \frac{g_{2}}{g_{1}} \cos \beta_{0}-m\left(\frac{3 X_{2}}{\pi}+r_{2}\right) \\
& B_{2}=1.35 \frac{m}{n} \frac{f_{2}}{f_{1}} \cos \alpha_{0}+m\left(\frac{3 X_{1}}{\pi}+r_{1}\right) \\
& B_{3}=1.35 \frac{m}{n}\left(\frac{f_{3}}{f_{1}} \cos \alpha_{0}+V_{1 a c 0} \sin \alpha_{0}\right) \\
& B_{d}=1.35 \frac{m}{n}\left(\frac{g_{3}}{g_{1}} \cos \beta_{0}+V_{2 a c 0} \sin \beta_{0}\right) \\
& T_{d}=L_{d} / R_{d}
\end{aligned}
$$

（1）順変換器定電流制御，逆变換器：定余裕 角制御の場合

(a)閉ループ余裕角制御 (46)式を(41) 式に代入する と余裕角制御系の関倸式は次の上うになる。

$$
\frac{d \Delta \beta}{d t}=\frac{k_{2} c_{1}}{T_{2}} \Delta I_{d}-\frac{1+k_{2} c_{2}}{T_{2}} \Delta \beta
$$

したがって，(40)，(47)，(48)式をまとめると次の上 う沈るる。

$$
\begin{aligned}
& \left(\begin{array}{l}
\Delta \dot{I}_{d} \\
\Delta \dot{\alpha} \\
\Delta \dot{\beta}
\end{array}\right)=\left(\begin{array}{ccc}
\frac{B_{1}-B_{2}-R_{d}}{T_{d} R_{d}} & -\frac{B_{3}}{T_{d} R_{d}} & \frac{B_{4}}{T_{d} R_{d}} \\
\frac{k_{1}}{T_{1}} & -\frac{1}{T_{1}} & 0 \\
\frac{k_{2} c_{2}}{T_{2}} & 0 & -\frac{1+k_{2} c_{1}}{T_{2}}
\end{array}\right) \\
& \cdot\left(\begin{array}{l}
\Delta I_{d} \\
\Delta \alpha \\
\Delta \beta
\end{array}\right) \\
& =\left(\begin{array}{ccc}
a_{11} & a_{12} & a_{13} \\
a_{21} & a_{22} & 0 \\
a_{31} & 0 & a_{33}
\end{array}\right) \cdot\left(\begin{array}{c}
\Delta I_{d} \\
\Delta \alpha \\
\Delta \beta
\end{array}\right)
\end{aligned}
$$

ただし，・=d/dt

（b）開ループ余裕角制御の場合 (36)，(42)， (47)式より次の関係式を得る。

$$
\begin{aligned}
\frac{d \Delta I_{d}}{d t}= & \frac{1}{T_{d} R_{d}}\left(B_{1}-B_{2}-R_{d}+\frac{B_{4} c_{1}}{c_{2}}\right) \Delta I_{d} \\
& -\frac{B_{3}}{T_{d} R_{d}} \Delta \alpha \quad \ldots \ldots \ldots \ldots \ldots \ldots . \ldots(51)
\end{aligned}
$$

したがって，この場合の状態方程式は次のようにな る。

$$
\begin{aligned}
& \left(\begin{array}{c}
\Delta \dot{I}_{d} \\
\Delta \dot{\alpha}
\end{array}\right)=\left(\begin{array}{c}
\frac{1}{T_{d} R_{d}}\left(B_{1}-B_{2}-R_{d}+\frac{B_{4} c_{1}}{c_{2}}\right)_{*} \\
\frac{k_{1}}{T_{1}}
\end{array}\right. \\
& \left.* \begin{array}{c}
-\frac{B_{3}}{T_{d} R_{d}} \\
-\frac{1}{T_{1}}
\end{array}\right) \cdot\left(\begin{array}{l}
\Delta I_{d} \\
\Delta \alpha
\end{array}\right) \\
& =\left[\begin{array}{ll}
a_{11} & a_{21} \\
a_{21} & a_{22}
\end{array}\right] \cdot\left[\begin{array}{l}
\Delta I_{d} \\
\Delta \alpha
\end{array}\right]
\end{aligned}
$$

(2) 順変換器: 定電流制御, 逆变均器: 定電王制 御の場合 (36)，(38), (43)式上り次の式省得百。

$$
\frac{d \Delta \beta}{d t}=-\frac{k_{3} B_{1}}{T_{3}} \Delta I_{d}-\frac{1+k_{3} B_{4}}{T_{3}} \Delta \beta
$$

したがって，この場合の状態方程式は次のようにな る。

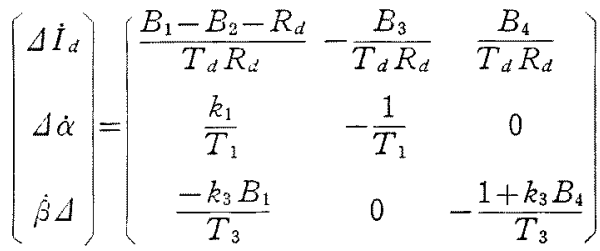

$$
\text { - }\left(\begin{array}{l}
\Delta I_{d} \\
\Delta \alpha \\
\Delta \beta
\end{array}\right)
$$

（3）順変換器: 定電力制御, 逆変換器: 定余裕角 制御の場合 順变換器が定電力制御の場合は(35), (37)，(45)式上り次式分成り立つ。

$$
\begin{aligned}
\frac{d \Delta \alpha}{d t}= & \frac{k_{5}\left(E_{d 10}-I_{d 0} B_{2}\right)}{T_{5}} \Delta I_{d} \\
& -\frac{1+k_{5} I_{d 0} B_{3}}{T_{5}} \Delta \alpha \ldots
\end{aligned}
$$

したがって，状㸃方程式は次のようになる。 


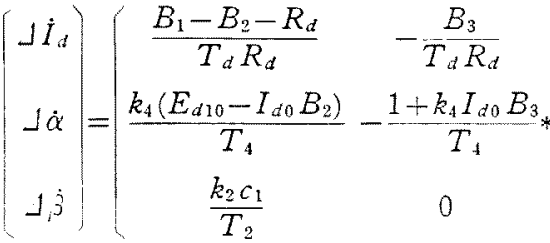

$$
\begin{aligned}
& \left.\begin{array}{c}
\frac{B_{4}}{T_{d} R_{d}} \\
-\frac{1+k_{2} c_{2}}{T_{2}}
\end{array}\right) \cdot\left(\begin{array}{c}
\Delta I_{d} \\
\Delta \alpha \\
\Delta \beta
\end{array}\right)
\end{aligned}
$$

なお，順变換器は無制御逆变換器が定電流制御，古 るい结湏变換器が定電流制御逆変換器が無制御の場合 の状態方程式仿，おのおの $\Delta \alpha=0, \Delta \beta=0$ 上招くこと 化上り求るることができる。

\section{3. 交流電圧安定度の判別条件と解析プログ ラム}

〈3.1) 交流電圧安定度の判別条件

(50)式の特 性根をとされば特性方程式は次のようになる。

$$
\left|\begin{array}{ccc}
a_{11}-\lambda & a_{12} & a_{13} \\
a_{21} & a_{22}-\lambda & 0 \\
a_{31} & 0 & a_{33}-\lambda
\end{array}\right|=0
$$

すなわち，

$$
\begin{aligned}
& \lambda^{3}-\left(a_{11}+a_{22}+a_{33}\right) \lambda^{2}+\left(a_{11} a_{22}+a_{22} a_{33}\right. \\
& \left.\quad+a_{33} a_{11}-a_{12} a_{21}-a_{13} a_{31}\right) \lambda+a_{12} a_{21} a_{33} \\
& \quad+a_{13} a_{31} a_{22}-a_{11} a_{22} a_{33}=0 \ldots \ldots \ldots \ldots(59) \\
& \lambda^{3}+A \lambda^{2}+B \lambda+C=0 \quad \ldots \ldots \ldots \ldots \ldots . . . .60
\end{aligned}
$$

したがって，(49)，(55)，(57)式の系む゙安定となる。 わには，特性根入の実数部が全へて負となればよい。 したぶって，フルビッツの安定判別条件により次の各 式が全べて成立しなけ机ばならない。

$$
\begin{aligned}
A= & -\left(a_{11}+a_{22}+a_{33}\right)>0 \ldots \ldots \ldots \ldots(6) \\
B= & a_{11} a_{22}+a_{22} a_{33}+a_{33} a_{11} \\
& \quad-a_{12} a_{21}-a_{13} a_{31}>0 \quad \ldots \ldots \ldots \ldots \ldots(6) \\
C= & a_{12} a_{21} a_{33}+a_{13} a_{31} a_{22}-a_{11} a_{22} a_{33}>0
\end{aligned}
$$

$A B-C>0$

しかし，(61)，(63)，(64)式が成り立てば(62)式も成 り立つので，結局，安定であるため纪は，(61)，(63)， (64)式が成立す机ばよい。同椂に(53)式が安定である ためには次の関係式が成り立つ必要がある。

$$
\left.\begin{array}{l}
A=-\left(a_{11}+a_{22}\right)>0 \\
B=\left(a_{11} a_{22}-a_{12} a_{21}\right)>0
\end{array}\right\}
$$

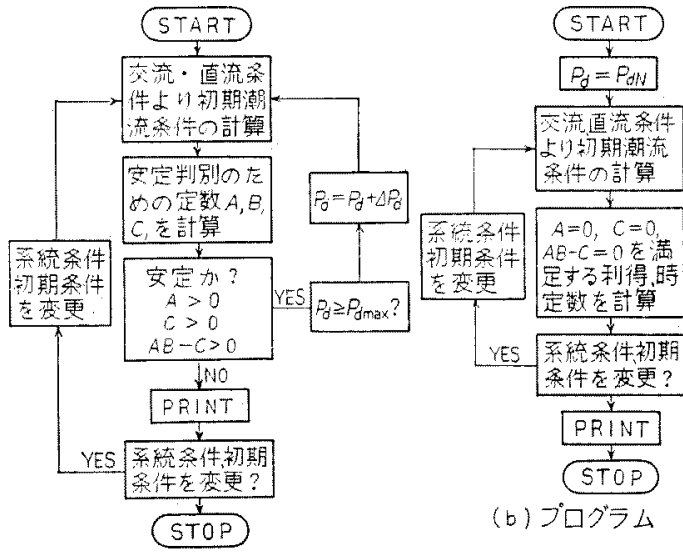

(a) プロブラム

第 3 図 交流電王安定度解析のフロー图概要

Fig. 3. Flow-diagram of $\mathrm{AC}$ voltage stability calculation.

〈3.2〉交流電圧安定度解析プログラム 解析プ ログラム注次の二通りを作成した。

(a) 直流電力を $P_{d}=0$ 加ら微小分 $\Delta P_{d}$ ステッ プで増加し，安定判別を行なうプログラム

(b) 定格直流電力 $P_{d N}$ を与えた埸合に安定限界 に㕲计る変撸器制期柔の利得之時定数の関倸在求好る プログラム

第 3 図は上記プログラムの榴略のフロー图を示した 白のであり，本プログラムの初期值の与无方は次の上 おりである。

（1）交流系の初期值 （i）系統のベース容量= $W_{B}(\mathrm{MVA})$, ベース電王 $=E_{B}(\mathrm{kV})$, (ii) 順・逆変換 器側交流系の短絡容量 $=W_{s 1}, W_{s 2}(\mathrm{MVA}),($ iil) 交流 楾路抵抗 $=r_{s 1}, r_{s 2}(\Omega) ，(\mathrm{iV})$ フィルタ+スタコン容量 $=Q_{c 1}, Q_{c 2}(\mathrm{MVar}),(\mathrm{v})$ 連系点負荷 $=P_{L 1}, P_{L 2}(\mathrm{MW})$ (vi) 逆变换㨐侧交流電王 $=V_{2 a c 0}(\mathrm{kV})$

(2) 檤流系の初期值（1変換器ユニットあたり）

(i ) 直流系容量 $=P_{d \alpha}(\mathrm{MW})$ (逆変換器に求ける), (ii) 御制角度 $\alpha, \beta$ (度), (吕) 変換器用变珐器のインピ ーダンス $=X_{t 1}, X_{t 2}(\%)$ (变正器容量ベース), (iv)直 流リアクトル $=L_{d}(\mathrm{H}),(\mathrm{V})$ 直流線路抵轨 $=R_{d}(\Omega)$, (vi) 变換器用变正器の变圧比 $($ 一次電圧 $/$ 二次電王 $)=$ $n_{1}, n_{2}$, (vii) 直流系の直列変换器数 $=m$ ，(Vii) 変換器制 御系の利得上時定教 $=k_{i}, T_{i}$

\section{4. 解析結果亡考察}

$\langle 4 \cdot 1\rangle$ 解析結果と模擬装置による実験結果の比較

開発した解析手法の累当性を確めため，解析結果之 模挨装置で実施した実験結果の比較を行なった。第 4 


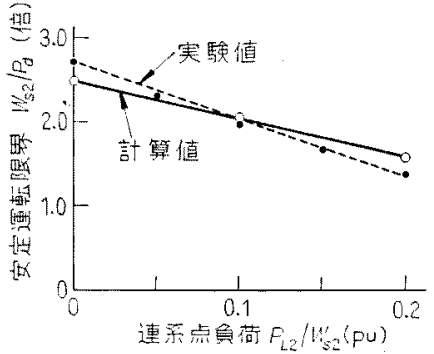

第 4 図 解析結果と実駼結果との比較

Fig. 4. Comparison between analytic results and experimental results.

図は連采点負荷を変えた場合の雨者で求めた安定運軽 限界の比較を示している。ただし，ての場合の采統条 件は次の上おりである。

短絡容量: $W_{\mathrm{s} 1}=\infty, W_{s 2}=22 \mathrm{kVA}$, 直流系の定格 容量: $P_{d N}=22 \mathrm{~kW}$, 変压器インピーダンス: $x_{t}=20$ $\%$, 制御角 $\alpha=15$ 度, 余裕角 $\delta=18$ 度, 定電流制御 柔の利得之時定数： $k_{1}=2,000$ 度 $/ I_{d N}(\mathrm{~A}), T_{1}=0.09$ 秒，定余裕角制御系の利得之時定数： $k_{2}=40$ 度/度, $T_{2}=0.2$ 秒, 直流りアクタンス: $L_{d}=0.48 \mathrm{H}$, 直流 線路抵抗: $R_{d}=6.4 \Omega$

第 4 图より明ら功ように実娩で求めた安定運䎐限 界は $P_{L 2} / W_{s 2}=0$ のとき $W_{s 2} / P_{d N}=2.75, P_{L 2} / W_{s 2}$ $=0.1$ のとき $W_{22} / P_{d N}=1.98$ であり, 解析では抢の おの 2.5 と 2.06 である。䛊差奆生じた主なる原因と しては，（i）線形化に上る䛊差，（ii）変換器の内部抵 抗や变殴器の損失に上る誤差, (吕)制御系の利得之, 時定数の模擬定数による犃差加热元ら机る。しかしな がら，解析により安定運転限界をモデル実椹より容易 かつ短時間化求められるので, 本解析の有利性が明ら かとなった。

〈4.2〉系統条件, 制御条件が交流電圧安定度に及ほ す影響 交直連系々統を想定し，本解析法を用いて 解析した結果を以下に示す。ただし，变換器の制御系 は順变換器が定電力制御, 逆变换器が定余裕角制御が 一般使用されているが，電圧安定度の基本的性質を はあくするために最も基本的な順变換器の定電流制御 と逆変換器の定余裕角制御について检討した。きた， 余裕角制御系は闒ループ方式とした。

（1）想定したモデル采統 想定した采統の定数 は次のと捄りである。

$P_{d N}=300 \mathrm{MW}( \pm 125 \mathrm{kV}, 1,200 \mathrm{~A}), \alpha_{0}=15$ 度, $\delta_{0}$ $=20$ 度, $x_{t 1}=x_{t 2}=20 \%, n=2.5(275 \mathrm{kV} / 110 \mathrm{kV})$, $Q_{c 1}=Q_{c 2}=90 \mathrm{MVar}, \quad L_{d}=1 \mathrm{H}, \quad R_{d}=0,10,20 \Omega$, $W_{s 1}=\infty, 1,500,3,000,4,500,6,000 \mathrm{MVA}, W_{s 2}=$ $300,600,750,900,1,050,1,200,1,500 \mathrm{MVA}, T_{1}=$

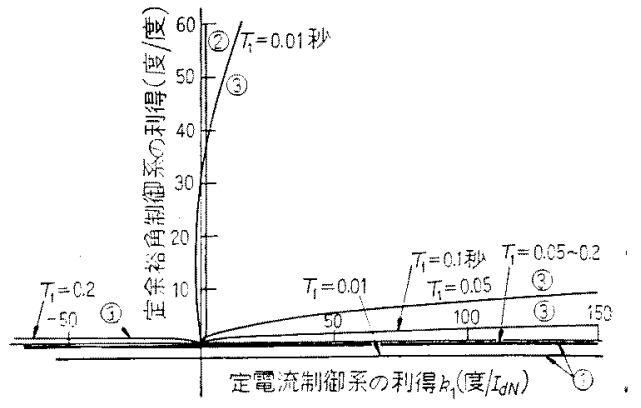

(a) $W_{s z}=750 \mathrm{MW} 0$ 䭪合

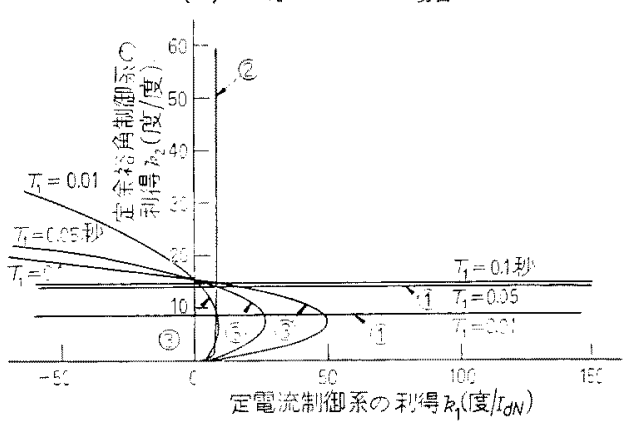

(b) $W_{s 1}=300 \mathrm{MW} 0$ 增弇

第 5 図 制御系のパラメータに対する安定運転 頒域 $\left(x_{s 1}=0, T_{2}=0.1\right.$ 秒, $\left.P_{d N}=300 \mathrm{MW}\right)$

Fig. 5. Stabrity rigion due to control parameters.

$0.01 \sim 1$ 秒， $k_{2}=0 \sim 10,000$ (度 $/ I_{d N}$ ), $\quad T_{2}=0.01 \sim 1$ 梨, $k_{2}=0 \sim 100$ (度/度)

なお, 計算ば逆変換器側の交直連系点電圧の初期檤 を $275 \mathrm{kV}$ に指定した平衡状態について行なった。

(2) 定電流制御采の利得之時定数が電圧安定度に

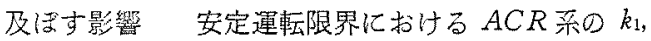
$T_{1}, A \delta R$ 柔の $k_{2}, T_{2}$ の関倸例第 5 図儿示す。ただ し, (a)は $W_{s 2}=750 \mathrm{MVA}$ で $W_{s 2} / P_{d N}=2.5$ 倍, (b) は $W_{s 2}=300 \mathrm{MVA}$ で $W_{s 2} / P_{d N}=1.0$ 倍のとき である。ここで，安定であるためには，直線(1)の上側 (安定条件の式 $A>0$ に相当)，(2)の右側（ $C>0$ に相 当), (3)の右側 $(A B-C>0$ 亿相当) 全べて満足しな け机ばならない。(a)図の $W_{s 2} / P_{d N}=2.5$ のとき, $T_{t}$ $<0.1$ 犁では安定, $T_{1}>0.2$ 秒では不安定となり, ま た，(b)図の $W_{s z} / P_{d N}=1$ では安定点は得られず, 常に不安定であることがわかる。通常， $k_{1}, k_{2}$ は定常 偏差ならびに過渡時のオーバシュートを㧕制する必要 から $500 \leq k_{1} \leq 5,000,20<k_{2}<80$ であり, 使用した模 擬装置では $1,500<k_{1}<4,000,40<k_{2}<80$ である。

第 6 図は定電流制御系の利得之時定数が安定限界汇 及ぼす影響を示している。てれより また，T隹小さいほど安定運転限界は向上し，電王 


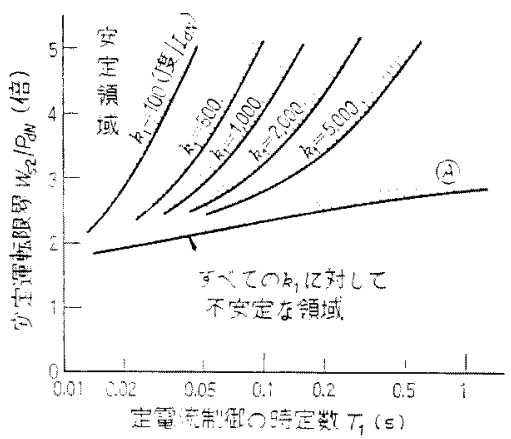

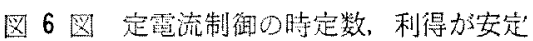

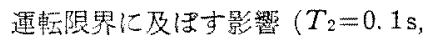

$$
k_{2}=40 \text { 度/度) }
$$

Fig. 6. Effect of time constant of $A C R$ to AC voltage stability.

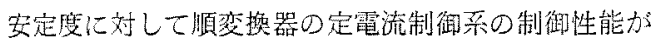
大きく影響するこしがわかる。すなおち， $T_{1}=0.01$ 梨 とすれば $k_{1}=100$ でも $W_{s} / P_{d N} \fallingdotseq 2$ まで安定に運轱

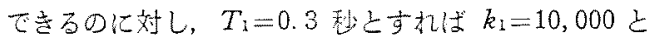
しても安定運軽限界は $W_{s 2} / P_{d N}=3.3$ である。また 同図 $A$ の曲線より $0.03<T_{1}<0.5$ 秒の籍国では利得 $k_{1}$ をいかなる值に選九て屯, 安㳬限界は $W_{s 2} / P_{d N}=$ 2.0 以下にならないことを示している。通賞は $T_{1}=$ $0.05 \sim 0.2$ 㤠程度であるのだ， $k_{1}=2,000$ とす机ば, $W_{s} / P_{d N}=2.5 \sim 4.3$ 七なる。

(3) 順变換器側交流系インピーダンスが電在安定 度に与え吕影響籍7図は順变換器側交流系のイン

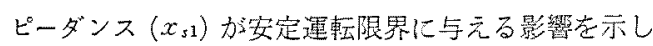
ている。ここで, $T_{1}=0.1, T_{2}=0.1, k_{2}=40$ とし, $x_{i 1}$ は1,000MVA, $275 \mathrm{kV}$ ベースとした。すなわち， 1,500MVA $0.666,3,000 \mathrm{MVA}$ は $0.333,6,000$

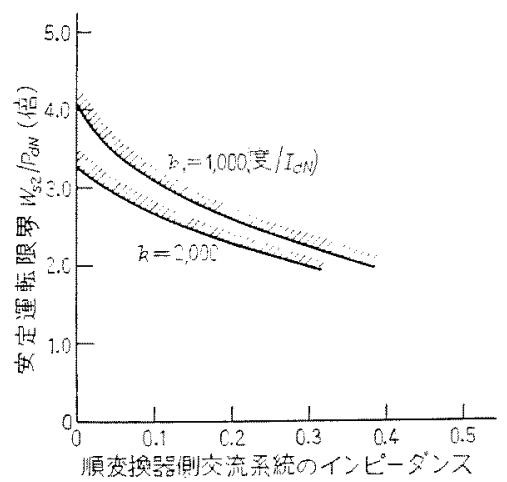

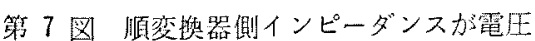
安定度に与える影得

Fig. 7. Effect of AC system impedance of rectifier to $A C$ voltage stability.

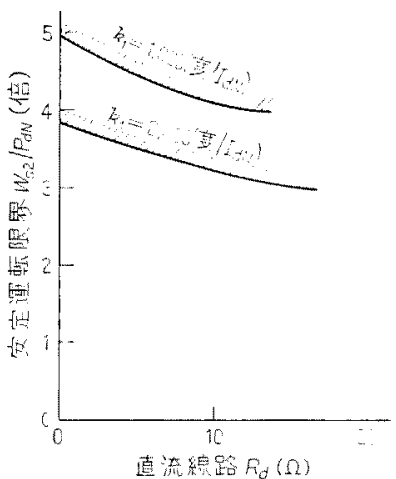

第 8 图直流線路加電生安定度に及ぼす影 響 $\left(T_{1}=0.1, T_{2}=0.1, k_{2}=40\right.$ 度/度 $)$

Fig. 8. Effect of DC line resistance to $A C$ voltage stability.

MVAは0.166に相当する。

このグラフから明らかなように，xsが大きいど 安定運軾限界は向上する。これは直流䉓流 $I_{d}$ が増加

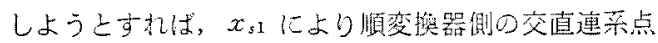

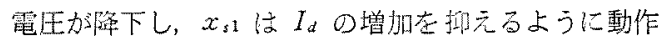
するからでする。

(4) 直流線路が電生安定然に及ぼす影䭗 第 8 図は直流線路 $\left(R_{d}\right)$ が大きいはご笽压安定度が问上す ること葆している。しれは $R_{d}$ が大きいと逆变器倪

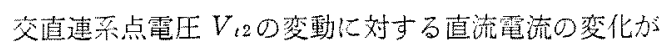
小さく，また直流回路の時定数が小さくなるため，等 僻的に定電流制御采の利得老大きくし，時定数索小さ くするためである。したがって，周波数变換所の上う に直流線路がない場合には電王安定度は簃しくなる。

（5）余裕角制御采の時定数之利得力゙電圧安定度に 及ばす影響第9図は閉ループ余枌角制御禿の時定

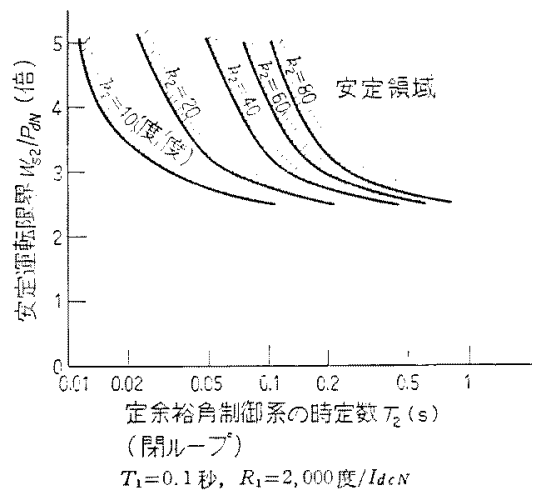

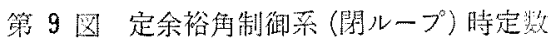
利得が電生安定度に及にす影罯

Fig. 9. Effect of time constant of $A \delta R$ to AC voltage stability. 


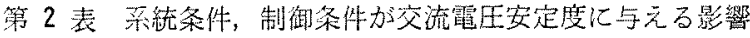

Table 2. Effect of AC-DC system conditions and control parameters to AC voltage stability.

\begin{tabular}{|c|c|c|c|c|c|}
\hline \multirow{2}{*}{$\begin{array}{l}\text { 染 } \\
\text { 件 }\end{array}$} & \multirow{2}{*}{\multicolumn{2}{|c|}{ 艾流電正实定度に及理す跑然 }} & \multicolumn{3}{|c|}{ 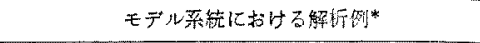 } \\
\hline & & & パラメータ0犆 & 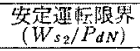 & 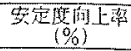 \\
\hline \multirow{4}{*}{$\begin{array}{l}\text { 隺 } \\
\text { 御 } \\
\text { 浐 } \\
\text { 件 }\end{array}$} & \multirow{2}{*}{ 濽交隐器 } & 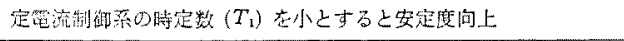 & $T_{2}=0.05$ & 2.56 & $(+) 21.2$ \\
\hline & & 定兆流制御棌の利得 $\left(k_{1}\right)$ を大とすると安定度低下 & $k_{1}=5,000$ & 2.80 & $(+) 13.8$ \\
\hline & \multirow{2}{*}{ 逆夜換器 } & 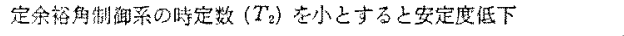 & $T_{2}=0.05$ & 5.0 & $(-) 53.8$ \\
\hline & & 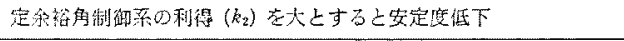 & $k_{z}=60$ & 4.1 & $(-) 26.2$ \\
\hline \multirow{3}{*}{ 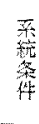 } & \multirow{2}{*}{ 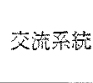 } & 国变換器側交䟽柔のインピーダンス $\left(x_{s_{1}}\right)$ を大とすると安定度向上 & $W_{s_{1}} / P_{d N}=30$ & 2.38 & $(+) 26.7$ \\
\hline & & 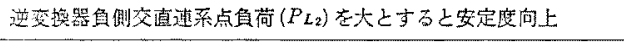 & $P_{L_{2} / P_{d N}=0.5}$ & 2.86 & $(+) 12.0$ \\
\hline & 㨁流稤維 & 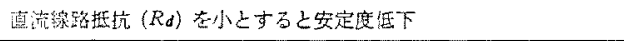 & $R_{d}=0$ & 3.8 & $(-) 16.9$ \\
\hline
\end{tabular}

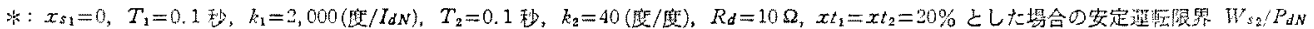

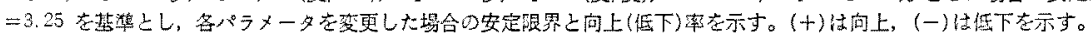

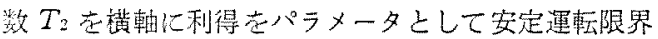
示したものである。これより明らかなように $T 2$ が小 さいほど，k2が大いほど電玨安定度が低下する。こ れは余裕角制御亲の㐫答特性が速いほど逆变鱼器倒交 流電壬变動に対して $\beta$ 角を大きく制御し，その結果 直流霞圧が变動して連系点電圧变動助長するた的で ある。したがって逆变換器側交流系統が小さい場合に は定余裕角制御系の時定数ならびに利得を古まり上げ るととができない。

また，開ループ余裕角制御の場合は第 9 図において 時定数 $T_{2}$ 功小さく，利得 $k_{2}$ む小さいところ相当 するが，詳しくは今捘険副する予定である。

以上の系統条件ならびに制御条件が電生安定度に与 える影響をまとめると第 2 表の上う炕なる。

\section{5. むすび}

交直連系々統の定常状態に怙汀る微小变動分に対し て，フルビッッの安定判別条件を適用した交流電压安 定度解析手法を開発した。モデル系統について解折し た結果，電正安定度を向上させる主なる要萃は

（1）定電流制御の時定数を小さくし，利得を大き
くすること

(2) 直流線路抵抗老大きくするこ上

(3) 順変換器側交流系統のインピーダンスを大き くすること

（4）逆变換器側交直速系点の負荷在大きくするこ 之

である。また，電圧安定度を低下させる主な要素は定 余裕角制御系の時定数を小さくし，利得を大きくする ことである。

終わりに，本研究の実施にあたり種々のご指導上有 益なるご討論をいただいた，電力中央研究所，技街第 一研究所電力符 2 部当任 尾出和也博土, 直流䒺統研究 室長町田武彦博士に深く感謝の意を表しま古。

(昭和 48 年 4 月 25 日受付, 同 48 年 9 日 11 再受付)

$$
\text { 文献 }
$$

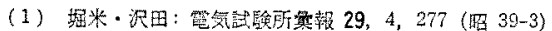

（2）吉田・町田..電中研技一研垁告 No. 70020 (昭 44-7)

(3) J.D. Ainsworth: Proc. Inst. Elect. Engrs 114, 1949 $(1967-7)$

(4) J. Kauferle, R. May \& Y. Rogowsky: IFEE Trans Power Apparatus Syst. PAS-89, 1610 (1970-9)

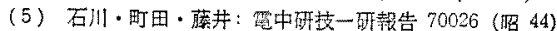

